\title{
PEMBELAJARAN SENI TARI DENGAN MENGGUNAKAN PENDEKATAN EKSPRESI BEBAS BERBANTUAN SOM
}

\author{
Hayani Wulandari \\ Universitas Pendidikan Indonesia
}

\begin{abstract}
Abstrak: Mahasiswa PGSD adalah mahasiswa yang memiliki latar belakang yang berbeda-beda. Namun yang pasti mereka adalah mahasiswa yang menekuni perkuliahan tentang ke SD an. Ketika mahasiswa bertemu dengan mata kuliah pendidikan seni tari dan drama, maka dampak yang terjadi pun akan beragam. Ada yang tidak punya pengalaman dalam menari, baru mengenal pemahaman tari pada saat mengambil perkuliahan pendidikan seni tari dan drama, tidak berani melakukan gerak karena malu, takut salah, grogi, tidak mau bergerak, apalagi sampai mengungkapkan sebuah ide kretaif, memikirkannya saja sudah membuat mereka enggan untuk berfikir dan berinovasi. Kemampuan mahasiswa PGSD sebagai calon guru diharapkan mampu untuk dapat terampil dan berinovasi di setiap pembelajaran yang ada di SD. Pendidikan seni tari dan drama merupakan salah satu mata kuliah praktek yang perlu dikuasai dan dipahami oleh mahasiswa PGSD. Untuk Mengatasi kendala tersebut maka mahasiswa perlu dibimbing dalam proses berkarya seni tari dan drama yaitu melalui pendekatan ekspresi bebas dengan berbantuan SOM. Mahasiswa akan lebih dapat menggali potensi terhadap pemikiran kreatif yang akan di kemukakan mereka dalam sebuah karya tari dan drama pendidikan. Berbantuan SOM akan mengarahkan mereka untuk dapat memberikan sebuah proses pembelajaran seni tari dan drama secara teknologi yang di dalamnya dilakukan secara bertahap serta disesuiakan dengan ide garapan yang akan dimunculkan.
\end{abstract}

Kata Kunci: Pembelajaran Seni Tari, Ekspresi Bebas, SOM, Mahasiswa PGSD

\section{A. PENDAHULUAN}

Belajar memberikan pengalaman tersendiri bagi setiap orang. Belajar tidak hanya dilakukan di dalam kelas, namun dapat dilakukan disekitar kehidupan masyarakat. Ragam cara dapat dilakukan untuk memperoleh hal-hal yang baik dari belajar. Terkadang orang akan benar-benar merasakan hasil dari belajar ketika berhadapan dengan masalah yang menghampirinya.

Beberapa orang menganggap bahwa belajar di dalam kelas itu yang utamanya adalah nilai yang dihasilkan. Dengan berbagai cara dapat dilakukan untuk memperoleh nilai yang baik, seperti mengikuti pelajaran tambahan, bimbingan belajar dan lain-lain. Namun terkadang ada juga yang menggunakan hal-hal yang tidak baik untuk mencapai apa yang diinginkan, seperti membuat contekan, kerjasama ketika ulangan, ataupun mencari kunci jawaban.
Bila perolehan hasil belajar dilakukan dengan cara yang tidak baik maka, belajar tidak memberikan pengalaman dan ketajaman intelektual bagi setiap individu, yang sebaiknya harus dapat disadari bagi semua pihak yang terkait dalam proses belajar tersebut. Cara pandang yang salah kaprah ini harus kembali ditempatkan ke dalam maksud dan tujuan belajar.

Siswa yang mengalami hambatan dalam belajar, sering kali di persalahkan hanya sebelah pihak oleh guru maupun orang tuanya. Padahal kecendrungan siswa kurang memahami materi yang diajarkan ada kemungkinan dari guru yang memberikan materi tidak dapat diterima oleh semua siswa, ataupun pembelajaran yang dilakukan guru tidak menarik.

Apabila hal ini terjadi, akibat dari pengemasan bahan ajar yang mengutamakan materi ajar harus segera selesai, atau pun guru hanya mengutamakan materi ajar tanpa 
memperhatikan sumber-sumber pendukung di dalam mengembangkan bahan ajar. Guru menganggap mengajar adalah sekedar menyampaikan materi pelajaran saja.

Guru pun pada akhirnya berjalan sendiri, padahal sebaiknya dalam proses pembelajaran akan lebih baik bila ada komunikasi dua arah antara siswa dan guru. Bila komunikasi dua arah ini tidak berjalan dengan baik maka, salah satu faktornya adalah tidak adanya kriteria yang jelas tentang keberhasilan guru dalam mengajar. Konsep mengajar yang hanya sekedar menyampaikan materi pelajaran, sehingga guru tidak merumuskan tujuan apa yang harus dicapai oleh siswa. Kehadiran guru dan siswa di dalam kelas sebaiknya tidak hanya sebatas hadir, namun harus adanya interaksi yang harmonis hingga akhirnya siswa akan memperoleh pengalaman belajar yang menyenangkan.

Makna pendidikan

pernah

dikemukakan oleh Kant (dalam Suparlan, 2004: 26)yaitu, "pendidikan tidak lain adalah sebagai upaya untuk memanusiakan manusia." Penjelasan lebih lanjut adalah memanusiakan manusia memiliki makna bahwa perlakuan yang diberikan kepada seorang anak manusia tidak boleh bertentangan dengan potensi kemanusiaannya, sesuai dengan harkat dan martabatnya sebagai manusia, yang bersifat unik dan memiliki perbedaan individu antara satu manusia dengan yang lainnya.

Pemaparan tersebut dapat dimaknai bahwa pendidikan tetaplah harus natural, sesuai dengan keadaan sebenarnya, tidak dapat memberikan kesamaan terhadap individu-individu yang berbeda-beda, serta disesuaikan dengan usia perkembangan siswa.

Era teknologi sudah masuk dalam ranah kehidupan kita saat ini. Tidak dapat dipungkiri bahwa siswa-siswa sekarang adalah generasi digital, mereka terlahir sudah terbiasa dekat dengan alat-alat teknologi. Tidak menjadi salah bila kita mengikuti perubahan teknologi yang bergerak dengan cepat, namun tetap teknologi harus dapat dipahami dengan lebih bijaksana.

Teknologi pun berpengaruh besar terhadap proses pembelajaran di sekolah. Dreiden dan Voh (dalam Suparlan, 2004: 67-68) mengungkapkan mengenai model revolusi pembelajaran yang diyakini dapat mempengaruhi cara belajar adalah:

1. Setiap orang adalah guru dan sekaligus murid.

2. Belajar akan sangat efektif jika dilakukan dalam suasana yang menyenangkan.

3. Ciptakan lingkungan yang baik sehingga anak-anak yang berasal dari keluarga miskin sekalipun akan berkembang dalam proses belajar mandiri.

4. Saat terbaik untuk mengembangkan kemampuan belajar adalah sebelum masuk sekolah karena sebagian besar jalur penting di otak dibentuk pada lima-enam tahun pertama.

5. Guru-guru yang cemerlang kini dpat mengajar jutaan orang melalui komunikasi elektronik interaktif dan meraup banyak uang dari pekerjaan yang mereka sukai.

6. Orang dapat belajar dengan baik ketika mereka mau belajar, bukan pada usia yang ditentukan oleh orang lain.

7. Kalangan tak mampu dapat memanfaatkan teknologi, kalangan yang bervisi jauh kedepan tentu dapat melakukannya dengan lebih baik.

8. Metode baru lebih berhasil dalam pelatihan karyawan.

9. Informasi yang komplek sekalipun diserap dengan mudah oleh siswa jika siswa benar-benar terlibat dalam proses pembelajaran.

10. Meskipun anda tertinggal di dalam sekolah, tidak ada kata terlambat untuk mengejarnya dengan metode belajar terpadu.

11. Penelitian menunjukkan bahwa kecerdasan/kemampuan tikus dapat berkembang dalam lingkungan yang tepat, demikian halnya dengan manusia. 
12. Teknologi belajar interaktif menyediakan beberapa kesempatan bisnis terbaik di dunia.

13. Tipe kecerdasan tidak hanya satu, setiap orang memiliki gaya belajar yang unik, sama halnya dengan sidik jari. Sekolah yang efektif harus dapat mengenali dan melayaninya.

14. Gunakan dunia nyata sebagai ruang kelas. Alam dan lingkungan merupakan sumber belajar dan sekaligus tempat kiat dapat belajar.

15. Komputer dapat mengubah berbagai aspek dalam belajar

16. Tidak harus menjadi negara besar untuk memimpin dunia. Yang paling menentukan adalah pemerintahan yang bervisi ke depan.

17. Sistem belajat cepat (accelerated learning) telah teruji, dan sisitem itu harus dimanfaatkan semua orang.

Bila mengamati paparan tersebut, maka perubahan ataupun revolusi pembelajaran akan mempengaruhi siswa dan guru baik secara langsung maupun tidak langsung. Adanya teknologi memungkinkan sumber belajar tidak hanya bersumber dari guru namun dapat diperoleh siswa dari media teknologi, seperti internet.

Penggunaan teknologi akan semakin besar pengaruhnya, maka guru bertindak sebagai fasilitator kepada siswa-siswanya. Guru pun harus dapat menggunakan alat atau media teknologi ini, hingga pada akhirnya akan bersama-sama dengan siswa untuk melaksanakan pembelajaran yang interaktif dan menyenangkan.

Mahasiswa PGSD sebagai calon guru Sekolah Dasar sudah seharusnya dapat berbuat lebih inovatif serta memiliki kemampuan berfikir kreatif hingga pada akhirnya disekolah mereka mampu memberikan pembelajaran yang dinamis bagi siswa-siswanya.

\section{B. Kajian Teori}

\section{Pembelajaran Seni Tari}

Pembelajaran merupakan

perubahan yang bertahan lama dalm perilaku, atau dalam kapasitas berprilaku dengan cara tertentu, yang dihasilkan dari praktek atau bentuk-bentuk pengalaman lainnya (Schunk, 2012).

Bila di telaah kutipan di atas terdapat tiga kriteria pembelajaran, yaitu:

a. Pembelajaran melibatkan perubahan

b. Pembelajaran bertahan lama seiring dengan waktu

c. Pembelajaran terjadi melalui pengalaman

Pada kriteria pertama adalah pembelajaran melibatkan perubahan. Orang dikatakan belajar ketika mereka menjadi mampu melakukan suatu hal dengan cara yang berbeda. Sementara itu kita harus ingat bahwa pembelajaran itu berkenaan dengan penarikan kesimpulan. Kita dapat mengamati pembelajaran secara langsung. Pembelajaran dinilai berdasarkan apa yang diucapkan, dituliskan, dan dilakukan seseorang. Akan tetapi peril kita pahami juga bahwa pembelajaran melibatkan berubahnya kapasitas untuk berprilaku dengan cara tertentu karena orang tidak biasa mempelajari suatu keterampilan, pengetahuan, keyakinan, atau prilaku tanpa mempraktikkannya pada saat pembelajaran sedang berlangsung.

Pada kriteria kedua adalah pembelajaran bertahan lama seiring dengan waktu. Pembelajaran bisa jadi tidak bertahan selamanya karena terjadinya lupa. Namun prilaku dalam proses pembelajaran tersebut yang akan terus bertahan lama. Untuk itu proses pembelajaran yang melibatkan prilaku harus terbimbing dan terarah hingga pada akhirnya akan meninggalkan bekas yanag dalam pada setiap prilaku yang berproses dalam pembelajaran tersebut.

Pada kriteria ke tiga adalah pembelajaran terjadi melalui pengalaman. Kriteria ini tidak mencakup perubahanperubahan perilaku yang terutama terbentuk karena faktor keturunan seperti perubahan-perubahan kematangan pada anak (misalnya:merangkak, berdiri). Meski demikian, perbedaan antara proses kematangan dan pembelajaran sering tidak bisa dipastikan secara jelas. Dengan demikian melalui perkembangan normalnya anak-anak bisa merangkak dan berdiri, 
tetapi lingkungannya harus responsive dan memberikan kesempatan pada terbentuknya prilaku-prilaku ini

Seni tari adalah ungkapan jiwa yang mengandung unsur keindahan dalam bentuk gerakan yang teratur sesuai dengan irama yang mengiringinya. Tari adalah keindahan gerak angota-anggota tubuh yang bergerak, berirama, dan berjiwa yang harmonis. Ada tiga unsur utama dalam tari, yaitu wiraga (fisik), wirahma (iringan musik), dan wirasa (penjiwaan atau ekspresi). Gerak tari dan gerak biasa memiliki perbedaan dalam hal kehalusan, dinamika (irama dan empo), dan iringan.

Pembelajaran seni tari bagi mahasiswa calon guru sekolah dasar, dapat menjadi salah satu upaya melestarikan seni tari. Hal ini sesuai dengan fungsi pendidikan, seperti yang dinyatakan Taba (dalam Ismiyanto 1999) bahwa pendidikan berfungsi sebagai pemelihara dan penerus kebudayaan, alat transformasi kebudayaan, dan alat pengembang individu peserta didik. Pendidikan seni sebagai salah satu bentuk pendidikan pada hakikatnya juga: (a) mewariskan kebudayaan; (b) mengupayakan pembaharuan kebudayaan; dan (c) memenuhi kebutuhan peserta didik. Kompetensi yang diharapkan dari pembelajaran seni di Sekolah Dasar adalah: (1) mampu memadukan unsur etika, logika dan estetika, meliputi: pengetahuan, pemahaman, persepsi, analisis, evaluasi, apresiasi, dan berproduksi melalui bahasa rupa, bunyi, gerak dan peran; (2) memiliki kepekaan inderawi, perasaan estetis dan artistik melalui pengalaman bereksplorasi, berekspresi dan berkreasi secara lintas bidang dalam mendukung kecerdasan emosional, intelektual, moral, spiritual dan adversitas sesuai dengan kebutuhan dan perkembangan siswa; (3) mampu berkreasi dalam bahasa rupa, bunyi, gerak dan peran dalam mengembangkan kemampuan perseptual, pemahaman, apresiasi, kreativitas, dalam berproduksi; (4) memiliki keterampilan dasar dan mampu berkreasi berdasarkan inspirasi yang bersumber pada alam dan lingkungan sekitar siswa dalam mengolah medium seni; (5) Mampu menghargai karya sendiri dan karya orang lain serta keragaman seni budaya setempat dan nusantara; (6) Mampu mempergelarkan, menyajikan karya seni dan atau merancang, memamerkannya di kelas dan atau di lingkungan sekolah (Depdiknas 2001: 8).

\section{Pendekatan Ekspresi Bebas}

Pendekatan ekspresi bebas

merupakan pembelajaran yang menggunakan model emerging curriculum yaitu proses pembelajaran yang tidak dirancang sebelumnya, tapi akan mengalami proses perkembangan atau improvisasi dalam proses pemebalajarannya sesuai dengan keinginan mahasiswa.

Proses yang digunakan akan berlanjut kepada dosen menanyakan kepada mahasiswa kegiatan yang ingin dilakukan akan seperti apa dan selanjutnya menyiapakan segala sesuatunya untuk memberikan kemudahan bagi mahasiswa untuk melaksanakan proses pembelajarannya.

Penerapan ekspresi bebas pada sekolah formal sebaiknya dilakukan secara terarah, karena dengan demikian dosen dapat melaksanakan kegiatan pembelajaran sesuai dengan jadwal yang sudah ditentukan, namun di stimulus dengan halhal yang memberikan kekuatan dan rasa ingin tahu mahasiswa yang lebih dalam.

Penerapan pendekatan ekspresi bebas secara terarah melalui strategi pembelajaran "pemberian motivasi" tersebut, merupakan strategi pembelajaran yang berpola intregrated (Andayani, 2002). Pendekatan ini merupakan pengajaran yang berpusat pada peserta didik, memberikan pengalaman langsung pada peserta didik, tidak ada pemisahan dengan bidang studi lain, menyajikan konsep dari berbagai bidang studi di dalam sebuah unit proses pembelajaran, dan hasil belajar dapat berkembang sesuai dengan minat dan kebutuhan peserta didik. Menyajikan konsep dari berbagai bidang studi di dalam sebuah unit proses pembelajaran. 
Pendekatan ekspresi bebas terarah yang diterapkan dalam mata kuliah seni tari dan drama ini, merupakan suatu strategi belajar mengajar yang berpusat pada peserta didik yang menjamin kebebasan peserta didik dalam berfantasi, berkreasi, dan membabarkannya. Kebebasan tersebut dibimbing atas dasar kesadaran, rasa tanggung jawab, dan disiplin sehingga bermanfaat dalam pembentukan dan perkembangan pribadi peserta didik yang baik.

Pengajaran dan bimbingan yang wajar secara teratur merupakan suatu proses pembelajaran untuk mengembangkan nilainilai imajinasi, intuisi, pikiran, kreativitas, dan kepekaan rasa. Implikasi nilai nilai tersebut menuju pada perkembangan siswa ke arah kedewasaan, pembentukan manusia yang kreatif dan berinisiatif, serta menjadi manusia yang dapat menghargai karya-karya seni, berwatak mulia, berbudi pekerti luhur, bersikap jujur, rendah hati, disiplin, setia, terbuka, toleransi, penuh perhatian, welas asih, dan adil.

Kesemua secara menyeluruh tercermin dalam sikap, kata, dan tindakan yang perlu dibelajarkan dan dibiasakan pada peserta didik. Peranan dosen membimbing perkembangan mahasiswa secara wajar sesuai dengan sifat-sifat yang dimiliki oleh manusia pada umumnya. Memberikan dasar untuk kegiatan-kegiatan selanjutnya bagi peserta didik secara bebas dan memuaskan dorongan untuk mencipta. Melalui strategi yang dapat berupa kegiatan "pemanasan" (strategi pembelajaran dengan pemberian motivasi), sehingga anak tetap dapat mengekspresikan dirinya sesuai dengan apa yang diharapkan.

Pemberian motivasi tersebut dapat berupa: pertama dengan bercerita atau berdialog dengan anak untuk membangkitkan perhatian dan rangsangan lahirnya motif yang dapat dijadikan dasar dalam berkarya. Tema ceritera atau dialog tentu saja yang me nyentuh kehidupan anak.

Cerita atau dialog akan menjadi menarik bila guru memperlihatkan foto, gambar atau film; kedua, memberikan anak pengalaman kontak langsung dengan alam secara sadar, misalnya dengan mengajak anak untuk mencermati keadaan sekelilingnya yang mungkin selama ini diabaikan seperti bunga-bunga yang tumbuh di sekeliling sekolah, kawat listrik dan telepon yang simpang siur, pejalan kaki serta kendaraan yang lalu lalang.

Untuk mengarahkan perhatian anak, guru dapat mengajukan pertanyaan, seperti: "warna bunga melati yang tumbuh di halaman sekolah dan berapa jumlah bunga yang sudah merekah, bagaimana sikap pejalan kaki yang menyeberang jalan, berapa meter tinggi tiang listrik", dan sebagainya. Ketiga, mendemontrasikan proses penciptaan karya seni rupa yang akan diajarkan.

Hasil penelitian sebelumnya yang dilakukan oleh Kusumawati, 2009 menyatakan bahwa siswa yang belajar dengan menggunakan pendekatan ekspresi bebas memberikan hasil yang lebih optimal dalam pencapaian hasil belajar seni tari.

Hasil penelitian Winarko (2010), meneliti hubungan ekspresi bebas dengan ekspresi terarah. Berdasarkan hasil analisis data tersebut, secara deskriptif menunjukan, hasil tes melukis dengan metode ekspresi terarah secara keseluruhan kelas VIII B SMP Tamansiswa Malang $47,5 \%$ adalah kurang, dengan ratarata kelas $69,25 \%$ adalah sedang. Hasil tes melukis dengan metode ekspresi bebas secara keseluruhan kelas VIII A SMP Tamansiswa Malang sebagian besar adalah sangat baik, sebanyak $45 \%$ dengan ratarata kelas 75,5 adalah baik.

Hasil penelitian Wardani (2010), dengan judul pengaruh metode pembelajaran ekspresi bebas terhadap hasil belajar seni musik ditinjau dari motivasi belajar siswa kelas VIII SMP Negeri 5 Denpasar. Berdasarkan hasil penelitian diperoleh bahwa siswa yang memiliki motivasi tinggi belajar dengan pengaruh metode pembelajaran ekspresi bebas akan memberikan hasil yang lebih optimal dalam pencapain hasil belajar seni jika dibandingkan dengan siswa yang memiliki motivasi rendah. 


\section{Berbantu SOM}

Penggunaan pembelajaran berbantu SOM (SCREENCAST O MATIC) adalah salah satu teknologi multimedia komputer. Berkaitan dengan hal tersebut Prakoso (2005) mengungkapkan tentang internet sebagai media pembelajaran memiliki karakteristik yang khas, yaitu: (1)sebagai media interpersonal dan massa, dalam hal ini internet dapat digunakan sebagai alat komunikasi antar individu maupun sekelompok pengguna; (2) bersifat interaktif, artinya pengguna dapat berinteraksi dengan pengguna lainnya ataupun dapat berinteraksi dengan fasilitas internet dari situs-situs tertentu; (3) memungkinkan komunikasi secara sinkron atau asinkron, dalam hal ini komunikasi yang terjadi melalui internet dapat dilakukan seketika itu juga (sinkron) dan dapat dilakukan dengan sistem tunda misalnya melalui electronic mail (asinkron). Selain itu Clellan (2004) mengemukakan bahwa pembelajaran menggunakan internet dapat dilakukan dalam berbagai bentuk, diantaranya yaitu:

a. Tutorial, dalam program ini internet berperan sebagai tutor dalam pembelajaran dimana pengguna mendapatkan informasi mengenai bahan ajar yang diinginkan sekaligus dapat mengevaluasi pemahaman dirinya melalui tes personal yang telah tersedia pada situs yang bersangkutan.

b. Virtual classroom, yaitu pembelajaran yang biasa dilakukan di kelas dapat dilakukan melalui internet dengan menggunakan electronic mail (e-mail) ataupun dengan penggunaan groupware dimana sekelompok pengguna menggunakan software yang sama sehingga dapat mengakses situs pembelajaran tertentu yang diinginkan.

c. Correspondence course, yaitu suatu pendekatan pembelajaran dimana rumusan materi ajar seperti silabus dapat diakses melalui internet dan siswa dapat belajar secara individu, melalui komunikasi interaktif melalui email dan pengumpulan tugas-tugas pembelajaran juga dikumpulkan melalui internet.

d. Project-based education, yaitu suatu program pembelajaran dimana siswa mengumpulkan informasi yang berhubungan dengan penelitian yang ingin dilakukan serta mengumpulkan laporan penelitian tersebut kepada dosen atau guru melalui internet.

e. Event-based education, dalam pembelajaran ini siswa yang berada dari Negara manapun dapat mengakses secara bersamaan ke dalam suatu situs yang menyajikan peristiwa-peristiwa penting yang terjadi di dunia. Seperti misalnya, NASA menayangkan peristiwa meluncurnya sebuah asteroid raksasa yang sedang menuju planet Saturnus. Para siswa yang mengakses ke situs yang telah ditentukan dapat menyaksikan peristiwa itu secara bersama-sama melalui internet.

SOM sebagai salah satu teknologi multimedia komputer memberi kesempatan serta mengembangkan kemampuan dosen dan mahasiswa dalam hal membuat karya seni dengan dibantu SOM dalam penyimpanan datanya. Sehubungan dengan meningkatkan berfikir kreatif, dengan berbantu SOM sangatlah memberi ruang yang dinamis bagi mahasiswa hingga tidak hilang data perekaman setiap fase penciptaan karya, khususnya karya seni tari untuk siswa SD.

\section{Pembahasan \\ Penerapan pendekatan ekspresi} bebas berbantuan SOM untuk meningkatkan kemampuan berfikir kreatif ,memberikan suatu alternatif pendekatan yang lebih memberikan kesempatan bagi siswa untuk mengembangkan kreatifitas yang dimilikinya.

Pembelajaran yang dikembangkan dalam proses pembelajaran seni tari ini, adalah metode yang sudah biasa digunakan oleh para guru dalam melaksanakan proses belajar mengajar seni tari dengan ceramah, 
Tanya jawab, imam, dan drill. Metode pembelajaran yang biasa digunakan guru Sekolah Dasar untuk mengajar dikembangkan menjadi pembelajaran seni tari yang menarik. Pembelajaran seni tari ini merupakan pembelajaran dengan menggunakan pendekatan ekspresi bebas, dan berbantuan dengan SOM. Model pembelajaran yang memadukan pendekatan ekspresi bebas, dan media teknologi dalam bentuk softwear diprogramkan melalui rencana pelaksanaan pembelajaran berdasarkan pada standar kompetensi dan kompetensi dasar yang ditarik dari Kurikulum Tingkat Satuan Pendidikan. Standar kompetensi di bidang seni tari ada dua yaitu apresiasi dan ekspresi.

Berdasarkan kajian teori maka, terdapat beberapa langkah yang dapat dilakukan dalam menggunakan pendekatan ekspresi bebas berbantuan SOM, yaitu:

1. Kegiatan pemberian motivasi, bercerita atau berdialog dengan mahasiswa mengenai tema yang akan diangkat dalam penciptaan gerak.

2. Memberikan kesempatan kepada mahasiswa untuk dapat mengungkapkan apa yang diketahui dalam kelompok dari tema yang akan diambil.

3. Setelah berdiskusi, dosen memberikan kesempatan selama 20 menit kepada setiap kelompok untuk mulai bereksplorasi gerak, mencari tiga gerak yang sesuai dengan tema yang diusung dengan setiap geraknya $2 \times 8$ hitungan.

4. Setelah 20 menit selesai, dilanjutkan dengan tampilan setiap kelompok

5. Evaluasi

6. Tugas selanjutnya adalah membuat rangkain gerak yang tadi sudah dibuat ke dalam SOM, langkah-langkah SOM sebagai berikut:

a. Download software SOM terlebih dahulu

b. Instal screencast

c. Setelah penginstalan, maka software dapat langsung digunakan tanpa harus melakukan registrasi, tampilan awal dari screencast o maticsebagai berikut:(1) Klik "use free version"untuk memulai merekam dengn versi gratis. Garis putus-putus menandakan daerah yang akan direkam; (2) klik tombol record; (3) lakukan perekaman sesuai yang kamu inginkan; (4) Proses merekam selesai klik done; (5) jendela editing klik video publish, save video

Catatan :

a. Jendela Editing, pada jendela editing hasil rekaman dapat dilihat terlebih dahulu, bila rasa masih ada yang kurang maka proses rekaman dapat di ulang dengan menekan tombol back untuk kembali ke proses rekaman.

b. Publish. Hasil rekaman dapat langsung di publish ke internet menggunak web atau youtube. Selain mempublish ke internet, hasil rekaman juga dapat disimpan dalam computer, untuk melakukannya tekan "publish to video file"

c. Save video. Simpan menjadi dalam format MP4, AVI, FLV, GIF. Hasil paling baik gunakan format MP4. Size rekaman dapat dipilih sesuai kebutuhan, note dan caption digunakan untuk memberikan catatan hasil rekaman.

d. Menu Option dipilih jika menginginkan hasil rekaman disimpan dengan menghilangkan tex tambahan, gerakan mouse, suara dari mmic, dan gambar dari webcam. Bila selesai editing pilih tombol "save video" pada pojok kanan bawah jendela editing.

Berdasarkan proses pembelajaran seperti yang telah diuraikan di atas, dapat digambarkan bagan pembelajaran seni tari dengan pendekatan ekspresi bebas berbantuan SOM terpadu berikut ini. 
Tabel 1.

Pembelajaran Seni Tari dengan pendekatan ekspresi bebas berbantuan SOM

\begin{tabular}{|c|}
\hline APERSEPSI \\
Pemberian motivasi, bercerita atau berdialog dengan tema yang \\
sudah ditentukan \\
INTI \\
PENDEKATAN EKSPRESI BEBAS \\
$\begin{array}{c}\text { Pembuatan materi tari pendek bertema dengan cara memberi } \\
\text { kebebasan kepada mahasiswa dalam proses ekspresi melalui } \\
\text { tahapan mencari ide dan konsep, penuangan ide dan konsep, } \\
\text { menghubungkan ide dan konsep, dan membuat jalinan ide dan } \\
\text { konsep, Tampil secara kelompok } \\
\text { PENUTUP } \\
\text { Pvaluasi dan Membuat rangkain gerak yang tadi sudah dibuat } \\
\text { dan di apresias kedalam SOM }\end{array}$ \\
\hline
\end{tabular}

\section{Kesimpulan}

Pembelajaran seni tari ini dilakukan dengan menggunakan pendekatan ekspresi bebas, berbantuan SOM. Dengan pembelajaran ini diharapkan mahasiswa memiliki wawasan yang lebih berkembang dan luas. SOM sebagai sebuah softwear merupakan alat bantu yang dapat mendokumentasikan gerak-gerak yang sudah diciptakan oleh setiap kelompok. Pendekatan ekspresi bebas memberikan kesemptan kepada mahasiswa untuk Ide siswa yang berbeda-beda akan memunculkan konsep yang berbeda pula. Pendekatan ekspresi bebas ini memberikan ruang dan waktu bagi siswa untuk bebas berekspresi dan berkreasi. Mahasiswa bebas menuangkan ide dan konsepnya dalam bentuk garapan gerak tari yang sederhana. Peran dosen di sini, sebagai fasilitator saja. Apabila ada ide dan konsep yang sama diantara mahasiswa, pasti penuangan ide dan konsepnya berbeda. Setelah mahasiswa memiliki ide dan konsep, dosen meminta mahasiswa menuangkannya ke dalam bentuk gerak tari. Mahasiswa menghubung-hubungkan apa yang ada di benak berkait dengan ide dan konsep akan menumbuhkan jalinan ide, konsep dan menghubung-hubungkannya untuk mendapatkan sesuatu yang baru. Berangkat dari menghubung-hubungkan apa yang ada di benak berkait dengan ide dan konsep dari hasil proses apresiasi, akan menumbuhkan jalinan ide, konsep dan akhirnya akan menghasilkan sesuatu yang baru. Dalam proses ini, siswa sudah bisa dikatakan melalui proses penciptaan karya seni tari.

\section{E. Daftar Pustka}

Kraus, Richard. 1969. History of The Dance In Art And Education. New Jersey: Prentice Hall inc. Englewod Cliffs.

Munandar, Utami. 1999. Kreavitas dan Keterberatan Strategi Mewujudkan Potensi Kreativitas dan Bakat. Jakarta : PT. gramedia.

Prakoso, Kukuh S. (2005). Membangun ELearning dengan Moodle. Jakarta. 
Metodik Didaktik Vol. 10, No. 1, Juli 2015

Schunk, Dale H. (2012). Learning Theorities. Pustaka Pelajar-Jakarta.

Suparlan, Suharsono.(2004). Masyarakat dan Kebudayaan Perkotaan . YPKIK.

Wardani (2010). Jurnal: Pengaruh Metode Pembelajaran. Jakarta.

Winarko. (2010). Skripsi: Hubungan Ekspresi Bebas dengan Ekspresi Terarah. Malang. 